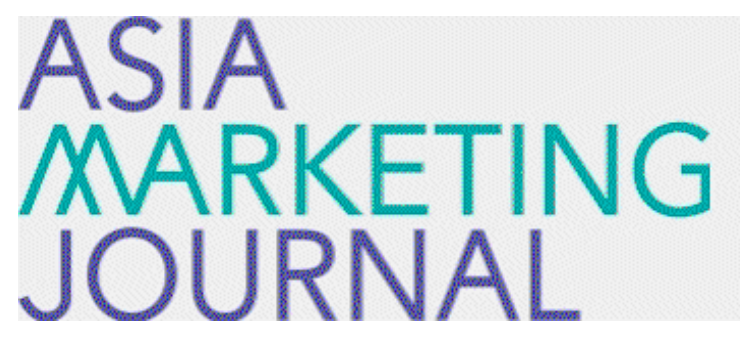

ASIA MARKETING JOURNAL

Volume 2 | Issue 1

Article 4

$3-1-2000$

\title{
4P 스키마타를 넘어서
}

In Soo Chun

II Hyun Bae

Follow this and additional works at: https://amj.kma.re.kr/journal

Part of the Marketing Commons

\section{Recommended Citation}

Chun, In Soo and Bae, II Hyun (2000) "4P 스키마타를 넘어서," Asia Marketing Journal: Vol. 2 : Iss. 1 , Article 4.

Available at: https://doi.org/10.53728/2765-6500.1032

This Article is brought to you for free and open access by Asia Marketing Journal. It has been accepted for inclusion in Asia Marketing Journal by an authorized editor of Asia Marketing Journal. 


\title{
4P 스키마타를 넘어서: 갭 스키마타 \\ Beyond The 4P Schemata: The Gap Schemata
}

\author{
전인수(홍익대학교 경영대학 경영학과) \\ jiss@wawhongik.ac.kr \\ 배일현(홍익대학교 대학원) \\ baeih102@unitel.co.kr
}

McCarthy(1960) 이후 오랫동안 4P 스키마타에 대한 논의가 없다시피하다가 Waterschoot and Van den Bulte(1992)가 특히 촉진믹스에 문제가 많음을 지적함으로써 마케텅믹스 분류체 계에 대한 논의가 다시 시작되었다. 하지만 이들 논의 내용 또한 '4P 스키마타'를 재해석 하는 정도이지 이를 넘어서지는 못하고 있다. 펄자들은 4P 스키마타의 한계점을 Hunt(1983, 1991)의 스키마타 평가기준에 따라 크게 네 가지로 지적한다. 먼저 분류대상의 속성이나 특징이 명확하지 않고, 다음으로 실무의 흐롬을 제대로 반영하지 못하여 유용성에 문제가 있으며, 세 번째로 분류된 범주간에 배타성과 포괄성이 부족하다. 끝으로 4P 간에 순서나 위계가 없어 문제의 진단이나 투자의 효율성을 논의하기가 어렵다.

이런 점들을 고려하여 연구자들은 4P를 원점활동과 접점활동으로 나누고 Parasuraman, Zeithaml, and Berry(1985; 1988 a,b; 1994)의 갭 모델을 원용하여 마케팅믹스의 새로운 분류체 계인 '갭 스키마타'를 제안한다. 갭 스키마타는 고객 잽과 마케터 갭 $1,2,3,4$ 로 구성된다. 고객 갭이란 고객의 기대와 지각간의 차이 즉, 고객만족을 뜻하고 갭 1 이란 마케팅조사를, 갭 2,3 은 원점활동을, 갭 4 는 접점 활동을 지칭하다. 원점활동인 갭 2 란 상품기흭, 브랜덩, 가격책정으로 구성되며; 갭 3은 광고 및 판촉으로 구성되고; 갭 4는 유통 및 물류, 인적판 매내지는 영업, 고객서비스로 구성된다.

논문접수: 99.11 게재학정: 00.4 


\section{1. 문제제기}

1953년 AMA(미국마케팅학희) 희장연설에서 Neil Borden이 "시장에서 어떤 반웅을 얻는 데 유용한, 요소의 혼합" 이란 의미의 마케팅믹스(marketing mix)란 개념율 처음 소개한 이래 여 러 마케팅학자가 이를 구체화시키는 노력을 해왔다(Waterschoot and Van den Bulte 1992). 특히 Oxenfeldt(1962)는 시장에서 어떤 반웅을 얻는 데 영향을 미치는 요소 다수를 항목화하려 했 고, Frey(1956)와 Borden(1964)은 체크리스트률 만들어 이률 보다 쉅게 정리하려 했다. 예컨 대, Borden(1964)은 제조업체 마케팅믹스의 요소로 상품기힉, 가격책정, 브랜딩, 유퉁경로, 인 적 빤매, 광고, 판촉, 포장, 다스풀레이, 서비스, 물류, 사실발견 및 분석 등을 끕고 있다. 이들 외에 여러 학자들이 보다 윕게 기역되고 체계화될 수 있는 분류체계 즉, 스키마타(schemata) 률 제시하였으나, McCarthy(1960)가 제시한 4P식 분류체계률 지배적인 견해로 받아들여 오늘 에 이르고 있다. 이는 간졀하고 기역하기 웝기 때문에 학계나 실무에서 부동의 스키마타로 자리률 잡고 있으나, 이를 비판하여 수정하려는 학자들에 의해 '전뿡적 마케팅믹스'라 블리 기도 한다(Booms and Bitmer 1981).

그러다 1980 년대에 접어들면서 여러 학자들이 $4 \mathrm{P}$ 식 분류체계의 문재점을 지적했는데, 특 히 촉진믹스(광고, 훙보, 판촉, 인적판매)의 문제점을 많이 지적하고 있다(예: Ailloni-Charas 1984; Bennett 1988; Cravens and Woodruff 1986; Kotler 1997). 이들 대부분은 마케팅교재 집필의 편의상, 분류의 문제점을 지적했을뿐 논문으로 이를 지적한 연구자는 Waterschoot and Van den Bulte(1992)가 대표적이다. 이들은 $\operatorname{Hunt}(1983,1991)$ 가 제시한 스키마타를 검토하는 다섯 가지 기준으로 기존의 $4 \mathrm{P}$ 식 분류체계, 이른바 ' $4 \mathrm{P}$ 스키마타'의 문제점을 지적한다. 예컨대, “스키마타가 분류하고자 하는 현상을 적절혀 규정하고 있는가?”라는 첫 번째 기준조차도 4P 스키마타는 깨풋하게 툼과하지 못한다고 비판하면서 새로운 믹스를 제시하고 있다. 이들은 재품믹스, 가격믹스, 유퉁믹스, 커뮤케이션믹스(매스컴믹스, 인적판매믹스, 훙보믹스) 둥의 4 가지를 기본믹스라고 하고 촉진믹스는 따로 구분하고 있다. 이때 사응하는 촉진이란 우리가 통상적으로 알고 있는 판촉을 의미하며 제품촉진믹스, 가격촉진믹스, 유퉁촉진믹스, 매스컴 촉진믹스, 인적판매촉진믹스, 훙보촉진믹스 둥을 촉진믹스로 분류하고 있다. 결국 마케팅믹 스란 '기본믹스'와 '촉진믹스'로 구성된다고 보는 견해이다.

필자들은 이돌의 비판과 제안을 보면서 촉진믹스를 보다 세분화했을 뺀 $4 \mathrm{P}$ 스키마타와 별반 다률 것이 없다는 생각이 둘어 $\operatorname{Hunt}(1983,1991)$ 가 제시한 다섯 가지 스키마타 평가기 준에 의해 전통적 마케텅믹스률 재검토하여 새로운 스키마타률 제시해보려 한다. 또한 4P 스키마타에서는 4P 간에 순서나 위계개념이 없다는 점도 연구과제로 다루어 보려 한다. 우 리는 습관적으로 $4 \mathrm{P}$ 의 맨 처음은 제품이고 맨 끝이 촉진이라고 생각하는데 왜 그런지에 대 해 논의한 문헌은 지금까지 찾기 어려욌다. 다만 분류하기 용이한 것은 앞에서 분류하고 애 
매한 것을 뒤로 물아서 기타범주(other category)로 묶었다는 견해는 있다(Waterschoot and Van den Bulte 1992). 기타범주란 촉진믹스률 지칭한다. 본 연구는 $\operatorname{Hunt}(1983,1991)$ 의 스키마타 평 가기준에 더 부합하고 더 나아가 순서나 위계도 있는 마케팅믹스의 새로운 스키마타률 모색 하는 데 연구의 목적을 두고 있다. 연구방법은 문헌연구률 바탕으로 하였고 마케터률 상대 로 한 심충면접(depth interview)으로 이를 보완하였다.

2. 4P 스키마타 및 마케팅믹스 순서에 대한 검토

2-1. Hunt $(1983,1991)$ 의 평가기준에 의한 $4 \mathrm{P}$ 스키마타 검토

Hunt $(1983,1991)$ 의 다섯 가지 스키마타 평가기준에 $4 \mathrm{P}$ 스키마타가 얼마나 부합하는지를 실무관점에서 검토하기로 한다. 실무관점이란 우리나라 기업에서 실제로 하고 있는 것을 중 심으로 논의한다는 뜻이다.

2-1-1.4P 스키마타는 분류대상을 적절히 규정하고 있는가?

전통적 마케팅믹스 즉, $4 \mathrm{P}$ 스키마타에서는 '마케팅활동내지는 기눙'을 분류의 대상으로 삼 고 있는데, 마케팅활동이란 과연 무엇인가?라는 문제를 제기할 수 있다. 즉, 마케팅부서에서 하는 활동인가 아니면 타부서에서 하는 활동이라도 시장반응에 직접적으로 영향을 미치면 모두 마케팅활동이라고 할 수 있는가?라는 문제이다. 우리나라 기업의 실정을 살펴보면 마 케팅부서에서는 마케팅조사, 상품기혁, 가격책정, 브랜딩, 광고 및 판촉 등을 담당하고 있고; 유통경로관리 및 물류는 영업부서에서; 고객에 대한 서비스는 고객지원부서에서 하고 있다. 이렇게 볼 때 마케팅부서에서 하는 일만이 마케팅활동인 것은 아니라는 사실은 분명한데, 그렇다면 마케팅활동을 어디까지 확장해야 하는가? 마케팅컨셉(marketing concept)을 고객초 점, 조정마케팅(coordinated marketing), 수익성 둥으로 정의하는 학자들은 마케팅할동을 전사 적인 것으로 규정하고 있다(Felton 1959; McNamara 1972). 이렇게 전사적으로 본 것은 마케팅 컨셉을 기업문화로 사용했기 때문이젰지만, 그렇더라도 마케텅할동의 확장을 시사하고는 있 다. 그렇기 때문에 스키마타의 분류대상을 마케팅부서, 영업부서 및 고객지원부서에서 하는 활동으로 확대할 수 있을 것으로 생각된다. 한편 $\operatorname{Kotler}(1997$, p.101)는 4P 외에 서비스와 판 매(sales force)률 따로 규정하고 있어 마케팅연구자들이 확장의 필요성을 느끼고 있옴을 짐작 할 수 있다. 
2-1-2. 4P 스키마타는 분류기준이 되는 속성이나 특징을 적절히 규정하고 있는가?

두 번째 질문에 답하기 위해서 세 가지의 질문을 새로 해야 한다. $4 \mathrm{P}$ 스키마타가 분류기 준인 속성이나 특징을 인식하고 있는가? 속성이나 톡징이 분류목적에 부합하는가? 누구나 이들 속성이나 특징으로 분류하면 같은 결과가 나오는가? 둥이다. 유감스럽게도 세 질문에 답할 수 있는 내용을 4P 스키마타에서 명학히 찾을 수는 없다. 그렇다면 사후적으로 4P 스 키마타로 분류된 활동들간에 공통된 속성이나 튝징을 갖추고 있는지률 검토할 필요가 있다. 이를 위해 먼저 $4 \mathrm{P}$ 간의 속성이나 특징의 차이률, 다음으로 각 믹스(이하 P로 지칭)내의 속 성이나 특징의 차이률 검토하기로 한다.

$4 \mathrm{P}$ 간의 가장 큰 차이는 유통경로P와 다륜 $3 \mathrm{P}$ 의 차이이다. 다른 $3 \mathrm{P}$ 는 단위제품별로 달리 이루지는 활동이면서 기업의 경계안에서 이루지는 활동이지만, 유퉁경로는 시스템으로 단위 제품에 따라 달라지는 것이 아니며 기업의 경계 밖에서 이루지는 활동이다. 또한 기업내의 담당부서도 마케팅부서가 아니라 영업부서이다.

다음으로 각 $\mathrm{P}$ 내의 활동들간에 속성이나 특징에서 어떤 차이가 있는지를 검토하기로 한 다. 가격을 제외하면 $3 \mathrm{P}$ 모두에 문제가 있다. 먼저 재품P로 분류하고 있는 $\mathrm{A} / \mathrm{S}$ 와 브랜딩은 제품을 구성하는 여타 속성인 포장, 디자인, 스타일, 품질, 보중 둥과는 과업의 성격이 근본 적으로 다른데, 특히 $\mathrm{A} / \mathrm{S}$ 는 시스템으로 단위제품에 따라 변하는 것이 아니다. 브랜딩 또한 최근에는 상표자산(Aaker 1998, p.173)의 관점에서 접근되기 때문에 단위제품을 넘어서 보다 장기적이며 포괄적인 톡성을 지니고 있다. 다음으로, 촉진믹스인데 광고, 판촉, 훙보, 인적판 매 둥과 같이 다른 $3 \mathrm{P}$ 로 분류하기 애매한 것을 모든 것을 기타범주(other category)로 몰아놓 은 것에 뷸과하다. 광고와 판촉은 마케팅부서에서, 훙보는 훙보부서에서, 인적판매는 영업부 서에서 각각 담당하여 속성과 특징이 다름을 잘 반영하고 있다(LG화학, 제일제당, 태평양, 삼성전자 둥의 조직도률 참고로 하였옴).

이상에서 $4 \mathrm{P}$ 가 공유하는 속성이나 특징을 현재 우리나라 기업의 조직도를 참고로 하여 검토해보았다. 전체적으로 유통경로가 이질적이고 각 $\mathrm{P}$ 내에서는 톡히 촉진믹스가 이질적인 데 이점에 대해 Waterschoot and Van den Bulte(1992)도 같은 견해를 보이고 있다.

\section{2-1-3. 4P 스키마타는 유용한가?}

4P 스키마타는 교재집필이나 마케텅과업 수행에 매우 유용하다고 보기 때문에 이미 실무 나 학계에서 이를 비판없이 받아들이고 있다. 하지만 마케팅믹스 자체에 대한 이론개발에 도움이 되지 않는다는 비판(Reidenbach and Olivia 1981, p.30; Sheth, Gardner, and Garett 1988, 
p.105)과 제품P가 제품컨셉에 국한되어 있어 제품과 관련된 여러 부서(생산, 원가, 영업, 디 자인)의 입장을 제대로 반영하지 못하고 있다는 비판도 있다(Wind and Robertson 1983).

필자들의 견해로는 이러한 문제보다는 최근에 기업의 성과로 중시되는 고객만족, 가치, 품 질 둥과 4P 스키마타가 제대로 연졀되지 않아 실무계의 흐름을 반영하지 못하고 있다고 본 다. 4P 스키마타에서는 고객만족을 기대뷸일치 패러다임으로 정의할 따름이지(Oliver 1997, p.99) 만족과 $4 \mathrm{P}$ 가 어떻게 연졀되는지률 제대로 설명하지 못하고 있다. 특히 모티베이선이론 인 Herzberg의 두 요인이론(dual-factor theory)이 Swan and Combs(1976), Maddox(1981) 둥에 의 해 고객만족을 설명하는 데 도입된 이후로 $4 \mathrm{P}$ 스키마타의 설명력은 떨어진다. 왜냐하면 두 요인이론에서 고객을 만족시키는 동기.8인(motivators)과 불만족을 줄여주는 위생요인 (hygienes)이 다르다고 보기 때문이다. Naumann(1995, p.53)은 불만족을 줄여주는 즉, 위생요인 으로 제품품질을, 만족을 촉진하는, 즉 동기요인으로 서비스품질을 재시하고 양자의 관계를 <그립 1>과 같이 나타내고 있다.

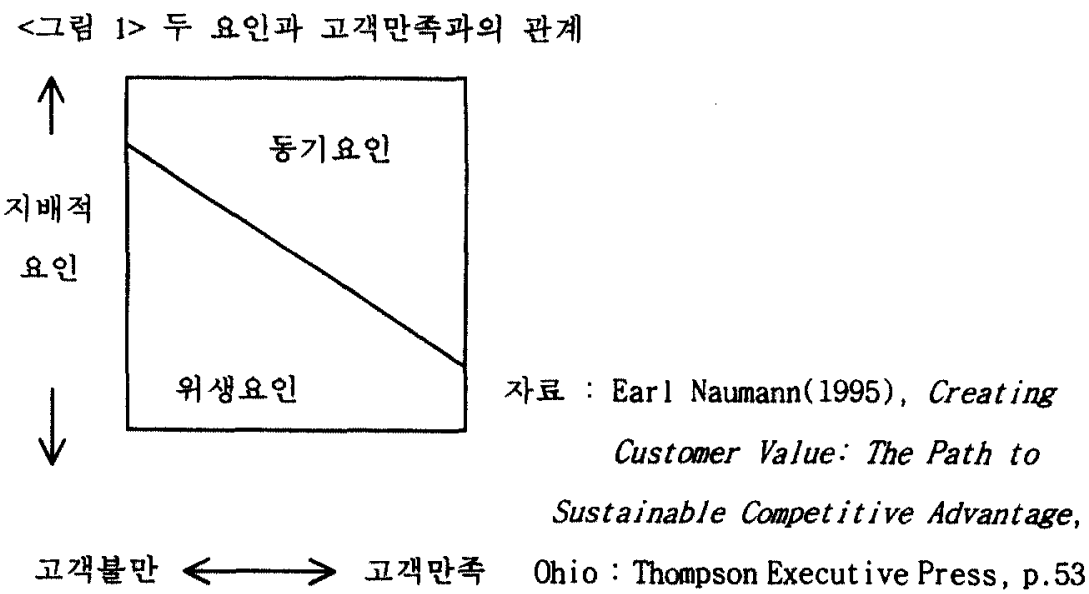

<그림 1>에서 보면 고객불만을 결정하는 지배적 요인이 위생요인이고, 고객만족을 결정하 는 지배적 요인이 동기요인이지만 양자는 어디까지나 '지배적임을' 알 수 있다. 또한 Naumann(1995, p.80)은 어떤 제공물이든 위생요인(예; 제품속성)과 동기요인(예; 서비스속성) 이 혼재돼 있다고 하면서 서비스를 판매전, 판매중, 판매후로 나누기도 한다.

2-1-4. 4P 스키마타는 포괄적(exhaustive)이면서 상호배타적인가(exclusive)?

촉진P가 다른 $3 \mathrm{P}$ 와 어느 정도 중복되더라도 배타성에서는 크게 문제될 것이 없다고 한다 
(Shapiro 1985). 그 이유는 촉진P가 '기타'범주에 속하기 때문이다. Hunt(1983, 1991)는 모든 분 류체계가 '기타'라는 범주를 만들면 모두 포괄된다고 한다. 하지만 너무 많은 현상이 기타범 주 외에는 마땅히 분류될 범주를 찾기 어려울 때 스키마타는 문제가 된다. 이러한 논리에 따르면 4P 스키마타는 지나치게 촉진P가 넓어 문제가 될 수 있다(Schultz 1987; Strang 1976).

이렇게 촉진P률 넓게 정의하더라도 새로 둥장하는 마케팅현상을 담아내기에 $4 \mathrm{P}$ 스키마타 는 역부족이다. 예컨대, 최근 들어 중시되고 있는 서비스마케텅의 내용을 담아낼 범주가 없 다. Zeithaml, Parasuraman, and Berry(1985) 둥은 서비스는 재화와 네 가지 측면(무형성, 이질 성, 생산과 소비의 동시성, 소멸성)에서 달라 마케팅의 내용이 다르다고 한다. 요컨대, 서비 스는 생산과 소비가 동시에 이루어지기 매룬에, 고객은 기업의 공장에 있는거나 마찬가지로 기업의 구성원과 직접 접촉하고 서비스의 생산과정애 실제로 참여하기도 한다. 또한 서비스 는 무형성이란 특징을 갖기 때문에 소비자가 느끼게 될 서비스경험을 미리 이해시킬 수 있 는 어떤 유형적인 단서가 필요하다. 그렇기 때문에 서비스마케터는 그들의 고객과 커뮤니케 이션하고 이듈을 만족시키기 위해 부가적인 변수들을 활용할 수 있다는 것이다. 예률 들어 호텔업에서는 종업원의 태도나 행동 이외에도 호텔의 설계와 장식이 고객의 지각과 경헙에 영향을 미치게 된다.

이러한 부가적 커뮤니케이션 변수들의 중요성을 깨달아 Booms and Bitner(1981)는 확장 된 마케팅믹스(expanded mix for services)'라는 새로운 개념을 제시했다. 서비스에 적용되는 화 장된 마케팅믹스란 전통적인 4P에 사랍(people), 물리적 중거(physical evidence), 과정(process) 등을 추가하여 $7 \mathrm{P}$ 를 말한다.

한편 Gronroos(1984)는 서비스의 특징 매문에 “서비스를 준비하고 가격을 책정하여 촉진시 키는" 외부마케팅(external marketing) 외에 이러한 할동이 잘 이루어질 수 있도록 도와주는 내부마케팅(internal marketing)이 필요하다고 하며, 더 나아가 서비스는 기술품질 외에 과정품 질 속성을 가지고 있기 때문에 상호작용마케팅(interactive marketing)이 중요하다고 한다. 이러 한 Gronoos(1984)의 견해률 살려 $\operatorname{Kotler}(1997$, p. 473)는 '서비스마케팅삼각형'을 제시한다. 외 부마케팅은 고객에게 '약속하기'를; 접점마케팅은 '약속지키기'를; 내부마케팅은 '약속지킬 수 있게 하기'를 각각 의미하며 이들 모두 제대로 됬을 때 서비스조직은 성공한다고 한다.

또한 하바드대학의 두 마케팅교수인 Bonoma(1984)와 Cespedes(1986)는 마케팅전략의 수립 과 집행을 구분하고 특히 집행이 기존의 마케팅믹스에서 간과되고 있다고 한다. Bonoma(1984)는 집행스킬로서 상호작용(interacting), 할당(allocating), 감시(monitoring), 조직화 (organizing) 둥을 들고 있어 집행은 전략의 수립과 달리 사람중심적이고 프로세스중심적인 시스템임을 암시하고 있다. Cespedes(1986) 또한 구조, 시스템, 프로세스가 업무의 성과를 결 정한다고 보는 영업(sales channel)과 서비스률 강조하면서 이들이 기존의 마케팅연구에서 둥 한시 되고 있다고 한다. Cespedes(1995)는 자신의 견해률 보다 구체화하여 마케팅전략의 집행 을 마케팅노력(marketing efforts)이라 하고 영업 및 고객서비스와 제품제공물 간의 연졀을 강 
조하고 있다. 그는 연결을 강조하기 위해 둥시마케팅(concurrent marketing)이라는 개념을 사용 하고 있다. 또한 Cespedes(1995, p.21)는 제품, 가격책정, 광고 둥을 전략적 마케팅으로; 고객 서비스와 영업을 전술적 마케팅이라 지칭하며 4가지 이유로 전술적 마케팅이 점차 중요해진 다고 한다. 제품수명주기가 점차 짧아지고, 시장이 파편화되며, 제품제공물이 서비스중심으 로 변해가고, 원재료나 부품의 공급이 사용중심으로 변해가기 때문이라고 한다. 이렇게 볼 때 4P 스키마타는 배타성에서 약간의 문제가, 포괄성에서는 실무의 흐름을 제대로 반영하지 못하는 문제가 있음을 알 수 있다.

2-2. 마케팅믹스 순서나 위계에 대한 검토

$4 \mathrm{P}$ 스키마타에서는 4P간에 어떤 위계가 있는지에 대해서는 논의된 바가 없는 것으로 알 고 있다. 기존 마케팅교재에서 제품, 가격, 유통, 촉진의 순으로 다루고 있어 위계라고 할 것 까지는 없지만 그런대로 어떤 순서가 있음을 함축하고 있다. 제품을 개발하여 출시하는 프 로세스상의 순서로 보면 제품과 가격에 이어 촉진이 오고 유통은 끝에 오는 것이 타당할 것 으로 생각되지만 그 순서가 뒤바먼 이유는 촉진이 '기타범주'에 해당되는 것으로 보기 때문 인 것으로 짐작된다. 굳이 $4 \mathrm{P}$ 간의 위계률 찾는다면 앞서 본 Bonoma(1984)와 Cespedes(1986) 의 마케텅전략의 수립과 집행을 구분하고 특히 집행의 중요성을 강조한 정도이다. 이처럼 순서나 위계가 없는 이유는 마케팅믹스를 단순히 혼합으로 보았지 이를 시장성과와 연결시 켜 문제의 원인을 진단하는 프로그램으로 활용하는 시도가 부족했기 때문으로 짐작된다.

하지만 서비스마케팅에서는 애기가 다르다. Parasuraman, Zeithaml, and Berry(1985; 1988 a,b; 1994; 이하 PZB로 지칭)는 서비스마케팅의 성과를 서비스품질로 보고 이를 진단하는 프로그 램을 '갭 모델(gap model)'이란 이름으로 제시하고 있다. PZB(1985; 1988a,b; 1994)는 고객의 서 비스에 대한 평가 즉, 서비스품질 평가률 '기대와 지각의 차이'로 정의하여 이률 '고객 갑 (customer gap)이라 부르고 있다. 이러한 고객 갭을 생기게 하는 원인을 '제공자 갭(provider gap)'내지는 그냥 갭이라 부르며, 4가지로 나누고 있다. 갭 1은 고객의 기대를 잘못 아는 것 을; 갭 2는 서비스를 잘못 설계하거나 표준을 잘못 설정하는 것을; 잽 3 은 서비스제공을 잘 못하는 것을; 갭 4는 커뮤니케이션을 잘못 하는 것을 각각 의미하며 다음과 같은 함수식으 로 나타낸다.

고객 잽 $=\mathrm{F}$ (갑 1 , 갭 2 , 갭 3, 잽 4)

이 함수식에서 고객 갭이란 기대서비스와 지각서비스 간의 차이를 말하며 잽 5 라고 표현 
하기도 한다. 한편 고객 갭을 생기게 하는 원인을 제공자 갭이라고 하고 주요 원인을 4 가 지로 구분한다. 갭 $1,2,3,4$ 는 그냥 구분하기 위해 붙여 놓은 이름이 아니라 일종의 문제진 단 프로그램으로 진단의 순서내지는 위계를 의미한다. 우선 서비스품질에 문제가 있다면 “고객기대률 제대로 지각했는지의 여부(갭 1)"를 따져 보고, 다음으로 “고객기대에 부합하는 서비스표준이 마련되고 또한 설계되었는지(갭 2)"를 검토할 수 있다. 이어서 “접점직원들이 제대로 서비스를 제공했는지의 여부(갭 3)"를 체크할 수 있으며, 끝으로 “고객에 대한 커뮤 니케이션이 제공되는 것과 일치하는지의 여부(갭 4)"를 검토할 수 있옴을 시사한다.

이렇게 불 때 갭 모텔은 일종의 스키마타로 '4P 스키마타'에 대비하여 '갭 스키마타'의 가 눙성을 시사한다. 양자간에 가장 큰 차이는 갭 스키마타에서는 고객과의 접점이 매우 중시 된다는 점이다.

\section{3. 새로운 분류체계: 갭 스키마타}

\section{3-1. 4P 스키마타의 한계점 요약}

앞서 4P 스키마타를 $\operatorname{Hunt}(1983,1991)$ 의 5가지 평가 기준으로 검토해본 결과 여러 문제점 이 지적되었다. 먼저 분류대상은 마케팅활동으로 규정하여 크게 문재뒬 것이 없었다. 다만 마케팅부서에서 하는 일만이 마케팅활동인 것온 아니라는 점을 지적하였다. 예컨대, 필자들 이 우리나라 주요 포장소비재 기업 10개 회사률 심충면접한 결과에 따르면(1997,3,10-3,15) 마케팅할동으로 상품기힉(컨셉, 특징, 품질, 출시시점의 결정), 가격책정, 브랜딩, 광고와 판 촉, 유퉁경로 관리와 물류, 영업내지는 판매, $\mathrm{A} / \mathrm{S}$ 를 포합한 고객서비스 둥을 끕고 있었다. 이 들의 상대적 중요성은 회사의 입장마다 달랐으며 담당부서도 제각각 이었다. 일반적으로 마 케텅부, 영업부, 물류부, 고객상담실 등이 가장 많았으나 어떤 회사는 마케텅부서 대신 기흭 부서에서 상품기혁이나 브랜덩을 담당하고 있었다. 한편 보다 세분화하여 상품기힉부서가 따로 있고 마케텅부서에서는 고객지원이나 판촉을 담당하는 경우도 있어 분류대상을 마케팅 부서에서 하는 활동이 아니라 마케팅활동으로 규정해야 함을 시사한다.

다음으로 분류대상의 속성이나 특징이 명학한지의 여부에서는 문제가 많은 것으로 나타났 다. 요컨대, 기타범주(other category) 때문에 촉진률ㄹ 구성하는 요소들간에 속성이나 특징에 문제가 많은 것으로 나타넜는데, 광고 맟 판촉과 인적판매가 매우 다르다. 특히 인적판매는 영업에 속하는 것으로 인적이면서 시스템적이라는 점에서 나머지 $3 \mathrm{P}$ 와 속성이나 특징이 일 치하지 않는다. 이렇게 볼 때 4P 스키마타가 첫 번째로 당면한 도전은 분류기준인 속성이나 특징이 범주마다 다르다는 점이다. 그렇기 때문에 분류기준올 하나의 연속선으로 정할 필요 
가 있다. 예컨대, 인적/시스템적 활둥과 비인적/비시스템적 할동으로 나눌 수 있을 것이다.

세 번째로 $4 \mathrm{P}$ 스키마타의 유용성 여부가 문제가 된다. 톡히 업계에서 강조되는 고객만족, 가치, 품질 등과 연결되지 않고 있다는 점이 문제다. 앞서 논의한 것처럼 두 요인이론에 의 하면 고객만족과 관련된 요인을 위생요인과 동기요인으로 나눌 수 있는데, 4P 스키마타에서 는 동기요인인 서비스(딴매전, 판매, 판매후)에 대한 분류가 없다. 4P률 고객과 마케터가 만 나는 접점에서 이루어지는 접점활동과 그렇지 않은 비접점할동으로 나눌 수 있다면 마케팅 믹스률 고객만족과 연결시키는 데 무리가 없을 것으로 본다.

네 번째로 포괄성에 문제가 있다. 최근 쟁점화되고 있는 서비스마케팅의 주요 활동을 포 괄하지 못하는 것은 고사하고 Bonoma(1984)와 Cespedes(1986, 1995)가 강조하는 마케팅전략 의 집행과 관련된 활동도 $4 \mathrm{P}$ 스키마타에서는 거의 언급되지 않고 있다. 물론 유통경로나 고 객지원 둥과 같은 접점활동이 $4 \mathrm{P}$ 스키마타에 포합돼 있지만 이는 부수적으로 취급되어 그 중요성이 반감되고 있다.

끝으로 문제를 진단하고 투자의 효율성을 높이기 위해서는 4P간에 순서나 위계가 펄요한 데 기존 4P 스키마타에는 이에 대한 논의가 없다. 작업흐름의 순서로 본다면 제품, 가격, 촉 진, 유통이 더 맞는데도 불구하고 촉진이 기타범주로 되어 있어 뒤로 밀려 있다. 하지만 최 근 PZB(1985; 1988 a,b; 1994)에 의해 개발된 갭 모델은 마케팅할동 간에 뚜렷한 위계률 두어 갭 $1,2,3,4$ 로 표현하고 있다.

이상에서 살펴본 바와 같이 연속선으로 예컨대, 인적/시스템적 활동과 비인적/비시스템적 활동으로 속성이나 특징율 구분하지 않은 점; 접점과 비접점을 구분하지 않아 고객만족과 연졀이 약한 점; 순서나 위계가 없는 점 둥이 $4 \mathrm{P}$ 스키마타의 한계점으로 꼽힌다.

\section{3-2. 새로운 스키마타를 위한 제안: 접점활동과 원점활동}

4P로 분류하여 무리하게 하는 것보다 오히려 범주률 포괄적으로 넓힌다면 비판으로부터 상대적으로 자유스러울 수 있다. 연구자들은 고객만족에 결정적 순간(moment of truth)이라고 하는 접점활동과 비접점이지만 접점활동의 바탕이 되는 활동을 원점활동이라 하여 마케팅활 동을 두 가지로 나눈다. 접점할동은 고객과 마케터가 직접 만나기 때문에 인적이며 시스템 에 의해 움직이는 특징을 갖고, 원점활동은 고객과 마케터가 직접 만나지 않기 때문에 비인 적이며 제품 마다 달리 졀정되므로 비시스템적이다. 또한 활둥이 이루어지는 공간도 주로 접점활동은 기업외부에서 이루어지고 원점활동은 내부에서 이루어지며 <그립 $2>$ 와 같이 상 호배타적이다. 
<그림 2> 원점활동과 접점활동의 관계

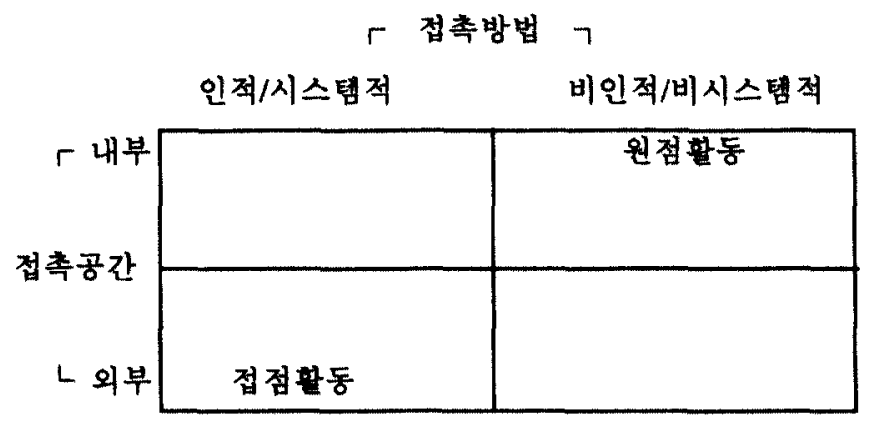

이렇게 두 활동으로 나누면 기존의 $4 \mathrm{P}$ 스키마타는 다음과 갊이 그 속성이나 특징에 따라 원점할동과 접점활동으로 분류둴 수 있다.

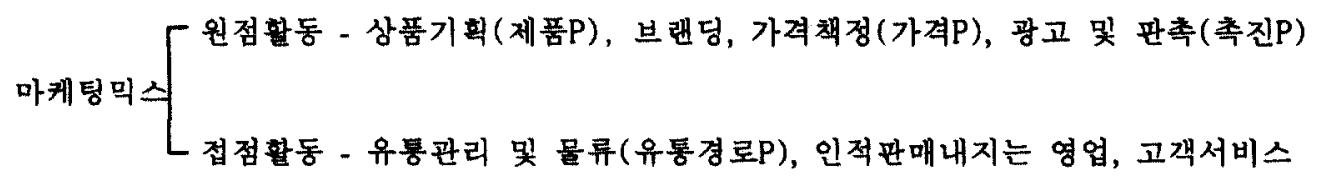

이렇게 분류하면 기존의 $4 \mathrm{P}$ 는 원점활동에 세 가지가, 접점활동에 한 가지가 포함되게 된 다. 다만 제품P에서 고객서비스와 브랜덩욜 독립시켜, 인적/시스템적 속성을 갖는 고객서비 스를 접점활동으로 분류하였다. 또한 촉진P에서 이질적인 속성을 갖는 인적판매를 때어내 접점활동으로 분류한 점도 새로운 점이다. 이렇게 분류하면 Hunt(1983, 1991)의 스키마타 검 토기준도 무리없이 통과할 수 있다.

먼저, 범주간의 속성이나 톡징의 동일성에 문제가 없다. 인적/시스템적인 속성이나 특징 을 가진 활동은 접점활동이고 비인적(물적/정보적)/비시스템적인 속성이나 특징을 갖는 활동 이 원점이기 때문이다. 여기서 원점이란 바탕내지는 뿌리라는 의미률 함축하고 있다. 다음으 로, 고객만족과 아주 잘 연결될 수 있어 실무적으로 매우 유용하다. Rust, Zahorik, and Keiningham(1995)은 품질에 대한 투자가 수익을 가져옴을 입중해보이고 있다. Lele and Sheth(1987)는 원점활동을 위생요인으로 접점할동을 동기요인으로 보고 둘 다 높은 것을 '난 공불락(unbeatable)', 원점할동온 높고 접점할동은 낮은 젓을 '절름발이(walking wounded)', 원 점 활동은 낮고 접점활동이 높은 것을 '시한폭탄(timb bomb)', 둘 다 낮은 것을 ' $\mathrm{DOA}$ ' 라고 하여 양자의 관계률 잘 설명해주고 있다. 또한 펄자들이 행한 조사에서 $4 \mathrm{P}$ 스키마타와 비교하여 양자 중 실무에 어느 분류가 적합한지 질문해본 결과 $90 \%$ 가 원점활동과 접점할동으로 나누 는 것이 더 편리하다고 한다. 
세 번째로 배타성과 포괄성인데, <그림 2>에서 보는 것처럽 범주간에 배타적이다. Bonoma(1984)와 Cespedes(1986, 1995)가 강조하는 마케팅전략의 집행과 관련된 할동이 바로 접점활동이고 또한 Booms and Bitner(1981)의 '확장된 마케팅믹스(expanded mix for services)' 중 3P인 사람(people), 물리적 증거(physical evidence), 과정(process) 등도 접점활동에 해당한다. 한편 Gronroos(1984)와 Kotler(1997, p. 473)가 말하는 상호작용마케팅(interactive marketing)도 접 점활동에 해당하는 것으로 볼 수 있다. 이렇게 블 매 포괄성에서도 별 다른 문제가 없는 것 으로 생각할 수 있다.

3-3. 새로운 스키마타: 갭 스키마타

마케팅믹스를 원점활동과 접점활동으로 분류하더라도 해결되지 않는 것은 마케팅믹스 요 소간의 순서내지는 위계문제이다. 또한 너무 범주가 크기 때문에 분류의 의미가 과연 있는 가?라는 비판을 받을 수 있다. 앞서 논의한 것처럼 마케텅활동의 목적을 고객만족내지는 품 질에 두고 PZB(1985; $1988 \mathrm{a}, \mathrm{b} ; 1994)$ 에 의해 개발된 갭 모델울 수정하여 만든 스키마타률 제 시하면 <그립 3>과 같다.

먼저 고객 갭인 고객만족은 기대불학정 패러다임에 의해 고객의 기대와 지각의 차이로 정의된다(Oliver 1997, p.99). 마케터 갭(PZB 모델에서는 이률 재공자 갭이라고 함)내지는 그낭 갭이라 부르는 4 가지 갭으로 접점활동과 원점활동을 나눌 수 있다. "고객의 기대를 잘못 알 아서 생기는" 잽 1은 마캐팅조사 미비나 잘못에 해당되고; “고객의 기대를 서비스표준이나 설계로 제대로 소화해내지 못해서 생기는" 갭 2는 상품기획, 브랜덩 및 가격책정의 잘못에 해당한다. "서비스률 제대로 제공하지 못하여 생기는" 갭 3 은 접점할동 즉, 유통경로 및 물 류, 고객지원, 인적판매내지는 영업 등의 잘못에 해당한다. 끝으로 "고객에게 약속한 것과 실제로 제공되는 것이 달라서 생기는" 갭 4는 광고나 판촉 및 $\mathrm{PR}$ 의 잘못에 해당한다.

하지만 이러한 분류에도 문제는 있다. 가격책정이 $\mathrm{PZB}(1985,1988 \mathrm{a}, \mathrm{b} ; 1994)$ 모델에서는 깁 4에 속하는데 이는 가격이 사실상 품질을 나타내는 유형화된 단서가 되기도 하기 때문이 다(Zeithaml 1988). 또 다른 문제점은 갭 스키마타의 잽 3,4와 PZB(1985, $1988 \mathrm{a}, \mathrm{b} ; 1994$ ) 잽 모델의 갭 3,4 가 일치하지 않는다는 점이다. 그렇기 때문에 PZB( $1985,1988 \mathrm{a}, \mathrm{b} ; 1994)$ 의 갭 모델에서와는 달리 필자들이 제안하는 마케팅믹스의 새로운 분류체계인 갭 스키마타에서는 


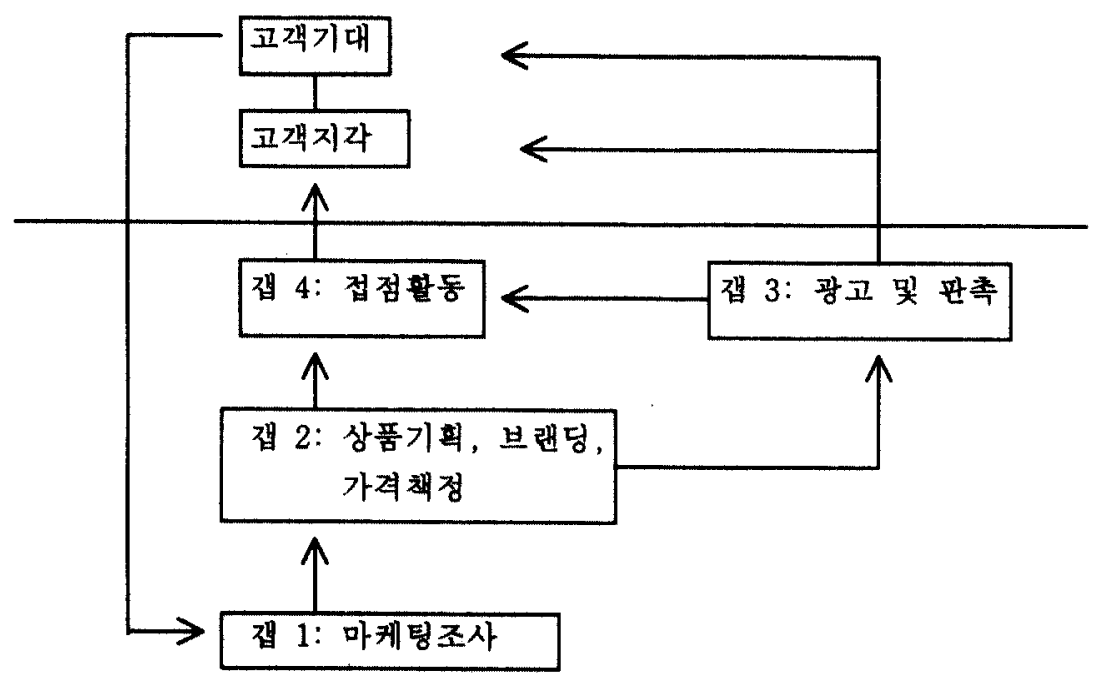

자료: 다음 논문을 바탕으로 작성하였음.

\section{A. Prasuraman, Valarie A. Zeithaml, and Leonard L. Berry(1985), "A Conceptual Model of Service} Quality and Its Implications for Future Reseach,“ Journal of Marketing, 49(Fall), p.44.

갭 3을 광고와 판촉(마케팅커뮤니케이션)에 해당하는 것으로 정의하고 갭 4 를 접점활동으로 정의하며 아래와 같은 함수식으로 정리된다. 이 함수식에서 말하는 '갭'이란 $\mathrm{PZB}(1985,1988$ $\mathrm{a}, \mathrm{b} ; 1994)$ 의 갭 모델( 이 모멜에서는 제공자 갭을 의미)에서와는 달리 마케터 갭을 의미한 다(이후에 나오는 갭이란, 단서가 없는 한 마케터 갭을 의미하는 것으로 사용한다).

고객갭 $=\mathrm{F}$ ( 갭 1 , 갭 2 , 잽 3 , 갭 4$)$

단, (1) 고객 갭 - 고객만족을 중심으로 한 소비자행동

(2) 갭 1 - 마케텅조사; 갭 2 - 상품기획, 브랜딩 및 가격책정; 갭 3 - 광고 및 판촉; 갭 4 - 유통관리 및 물류, 인적판매내지는 영업, 고객서비스

(3) 원점활동 - 갭 2 , 갭 3 ; 접점활동 - 잽 4

<그림 3>에서 보는 바와 같이 갭 $1,2,3$ 이 갭 4의 전제가 되기 때문에 원점활동으로 명명 한 것이다. 다만 이 경우 문제가 되는 것은 갭 1 인 마케텅조사인데 원점과 접점 어디에 속 한다고 하기 곤난하여 모두와 관련되는 것으로 본다. 이렇게 볼 때 갭 스키마타에서는 
Hunt $(1983,1991)$ 의 비판 외에도 4P 스키마타에서 해결하지 못한 두 가지률 추가로 설명하고 있다. 마케텅조사를 갭 1 로 수용하고 있으며 고객 갭으로 소비자행동을 담아내고 있다.

\section{4. 제안, 토의 및 연구의 한계}

\section{4-1. 제안 및 토의}

소비자의 기억과 관련된 이론으로 Kardes(1999)가 제시한 스키마(schema)이론이 있다. 스 키마란 인간이 갖는 선험적 지식구조를 말하는데, 마디(node)와 고리(link)로 구성된 일종의 네트워크이다. 각 마디 안에 들어 있는 내용을 소개념이라 하며 구체적일 수도 있고 매우 추상적일 수도 있다. 사람들은 좀처럽 기존의 지식체계인 스키마를 바꾸려 하지 않고, 새로 운 정보나 지식을 접하게 되면 기존 스키마와의 불일치 정도에 따라 동화(assimlation)와 조 정(accomodation)이란 정보처리과정을 거쳐 스키마를 수정하게 된다. 동화란 새로운 정보나 지식이 기존 스키마에 퉁합되는 것을 말하고, 조정은 새로운 스키마를 만들거나 기존 스키 마가 새로운 지식을 해석하고 정리하기 위해 기존 스키마률 수정하는 것을 말한다.

이런 논리에 근거하여 최우원(1999)은 신규진입제품이 기존제품을 넙어서기 위해 사용 하는 포지셔넝전략으로 세 가지를 제시하고 있다. 기존제품에 대한 고객의 스키마률 바꾸기 어렵다고 판단되거나 아직 스키마가 제대로 형성되지 않은 경우에 기존제품이 갖는 속성을 더욱 강화하여 선발이점을 극복하는 전략이 있고; 새로운 속성을 추가하여 기존 스키마를 수정하는 스키마플러스태그(schema plus tag)전략이 있으며; 기존 스키마로는 새로 부상하는 시장을 담아내지 못할 때 새로운 세분시장을 만드는 하위범주화(subtyping)전략이 있다.

McCarthy(1960)가 제시한 4P 스키마타는 마케팅믹스에 관한 스키마로 연구자나 실무자들 의 기억을 선점하고 있다. 이후에 제시되는 $4 \mathrm{P}$ 스키마타에 대한 비판내지는 수정 모델온 기 존제품에 대한 신제품의 도전으로 볼 수 있다. 앞에서 살펴본 Borden(1964)의 연구나 Waterschoot and Van den Bulte(1992)의 연구 및 Booms and Bitner(1981)의 연구는 4P 스키마타란 스키마를 더욱 강화한 것으로 불 수 있다. 한편 앞에서는 논의하지 않았지만 Kotler(1997, p.94)는 4P 대신 4C로 마케팅믹스률 나누고 있다. 제품P 대신 고객초점C(customer focus), 가 격P 대신 비용C(cost to the customer), 유통P 대신 편의 (convenience), 촉진P 대신 커뮤니케이 션C(communication)으로 각각 표현하고 있다. 하지만 $4 \mathrm{C}$ 란 $4 \mathrm{P}$ 률 다르게 표현했을 따름이지 그 내용이 다른 것은 아니기 때문에 이 또한 기존 스키마에 동화된다.

본 연구에서 제시하는 갭 스키마타는 기존 스키마률 조정한 즉, 스키마에 태그를 추가한 (schema plus tag) 점이 앞선 연구와의 차이다. $4 \mathrm{P}$ 스키마타가 가지고 있는 장점은 살리면서 새로운 내용이 추가된 것이다. 갭 스키마타가 보다 개선된 스키마로 연구자나 실무자들의 
기억에 안착하는지의 여부는 '새로움'과 그것의 '유용성'에 달렸다고 보아 다음과 같은 갱점 을 제시해본다.

먼저 4P 스키마타와 비교한 잽 스키마타의 새로움은 다음과 같다.

첫째, 마케팅성과률 갭 스키마타에서는 고객만족으로 정하고 있다. 기존의 4P 스키마타 에서는 이점이 분명하지 않아 마케텅믹스와 관련된 진단이나 개선 프로그램이 개발되지 못 하고 있다.

둘째, 갭 스키마타에서는 현실울 더 잘 반영할 수 있도록 하기 위해 고객만족의 동기요 인힌 접점활동과 위생요인인 원점활동으로 마케팅믹스률 나누고 4P 내용을 세분화시켜 원 점활동과 접점활동에 수용하였다.

셋째, $4 \mathrm{P}$ 스키마타에서는 속성이나 톡징이 공유되지 않는 활동이 한 범주에 묶여 있었으 4 깁 스키마타에서는 분류기준을 명확히 하여 이들을 분리시켰다. 제품P에 포함돼 있던 고 객서비스와 촉진P에 속해있던 인적판매를 따로 때어 접점활동에다 포함시키고 있는 것이 새 롭다. 굳이 P로 묶어 낸다면 이듈은 사랍믹스(people)로 표현할 수 있어 갭 스키마타의 구성 요소는 5P로 정리될 수도 있을 것이다.

넷째, 갭 스키마타에서는 마케터 잽 $1,2,3,4$ 로 마케팅믹스 간의 순서내지는 위계를 제시 하고 있다. 또한 $4 \mathrm{P}$ 스키마타에서 담아내지 못하고 있는 마케텅조사를 갭 1 로 담아내고 있 어 보다 현실적이다. 한면 <그립 3>에서 보는 바와 같이 갭 $2,3,4$ 가 고객의 지각과 기대에 영향을 미치는 것으로 돼있기 때문에 소비자행동의 중요성도 간접적으로 시사하고 있다.

이러한 차이점을 감안하지 않더라도 갭 스키마타는 $\operatorname{Hunt}(1983,1991)$ 의 스키마타 검토 다 섯 가지 원칙에 큰 무리없이 부합한다. 그렇다면, 즉 잽 스키마타률 받아 들인다면 학계나 실무계에 어떤 유용성이 있을까?

먼저, 마케팅교재의 편재가 달라질 수 있다. 고객 갭인 고객만족을 위시한 소비자행동이 맨 먼저 오고; 잽 1 인 마케팅조사; 갭 2인 상품기힉 및 가격핵정; 잽 3인 광고 및 판촉; 잽 4인 유퉁관리 및 물류; 갭 4인 영업내지는 빤매; 갭 4인 고객서비스의 순으로 편재가 이루 어질 수 있다. 기존 마케텅교재와는 순서가 다르고 새로운 영역이 부각된 점이 차이이다.

다음으로, 원점휼동은 원점마케텅으로 접점활동은 접점마케팅으로 각각 지칭하여 현실에 맞추어 마케텅담당자들의 지식을 쌓는 데 도움율 줄 수 있을 것이다. 원점마케팅이 마케텅 스킬 위주의 지식을 강조한다면, 접점마케팅은 시스템설계 및 사랍관리와 관련된 지식을 강 조한다. 앞서 살펴본 Bonoma(1984)와 Cespedes(1986, 1995)의 견해도 이와 일치한다. 특히 이 중 접점직원 관리는 기존 인사관리에서 다루고 있는 지식과는 다르다. 접점직원은 경계연결 역할(boundary spanning role)을 하기 때문에 선발, 교육훈련, 퉁제 및 보상에서 달라야 한다 (Lysonski 1985). 사내에서 근무하는 조직원과 달리 조직 밖에서 고객을 만나야 하기 때문에 업무능력 외에 요구되는 성향이 많기 때문이다. 예컨대, 배려성이나 친절성과 같은 서비스성 향이 필요하다고 한다(Schneider and Schechter 1991). 
세 번째로, 새로 나타나는 마케텅활둥을 담아 낼 수 있다. 요컨대, Borden(1964)이 제시한 마케팅활동도 담아낼 수 있고, 중요성이 더해가는 서비스마케텅의 외부마케팅과 상호작용마 케팅이란 개념도 원만히 소화해낼 수 있어 마케터가 업무를 수행하는 데 유용하고 학습자의 교육효과도 높일 수 있다.

끝으로 Kohli and Jaworski(1990)가 제안한 시장지향성(market orientation)을 새로 정의할 수 도 있다. 시장정보창출(intelligence generation)은 갭 1 에 해당하는 것으로 뷸 수 있다. 갭 2,3 에 해당하는 시장정보공유(intelligence dissemination)는 원점활동으로 뷸 수 있으며, 갭 4에 해 당하는 반웅(responsiveness)은 접점할동의 품질로 볼 수 있다.

\section{4-2. 연구의 한계}

서비스품질을 다른 PZB(1985, $1988 \mathrm{a}, \mathrm{b}, 1994)$ 의 잽 모델에 근거하여 갭 스키마타률 제안했 기 때문에 본 연구는 여러 한계률 안고 있다. 먼저, 마케팅의 성과률 과연 고객만족으로 불 수 있는가가 명학하지 않다. 이 점을 해결하기 위해 고객만족을 통해 매출중대도 가져오고 수익성도 높아진다는 확신을 가질 필요가 있다. 이 문제는 기존 연구에서 어느 정도는 입중 되고 있다(Rust, Zahorik, and Keiningham 1995).

다음으로, 갭 스키마타에서 중시하는 원점활동과 접점활동을 고객만족과 연결시키는 문제 가 있다. Swan and Combs(1976), Maddox(1981) 둥이 제시한 두 요인이론(dual-factor theory)으로 고객만족의 선행변수를 설명하는 것에 대한 논의가 아직 미진하기 때문이다.

세 번째로, 새로운 스키마타률 제안하면서 하필 부정적 표현인 '갭'이란 용어률 사용할 필요가 있는가라는 의문이 생긴다. 그렿기 때문에 갭 스키마타를 4P 스키마타와 별개의 분 류체계로 불 것이 아니라 상호보완적인 관계로 보는 것이 타당할 것이다. 즉, 마케텅과 관련 된 문제률 진단하고 새로운 대안을 모색하려 할 때 잽 스키마타의 유용성은 높아 질 것이 다.

네 번째로 가격믹스률 어느 갭에 분류할 것인가가 문제시 된다. 펄자들은 가격믹스률 갭 2 로 분류하였지만 가격믹스는 소비자에게 품질단서로서의 역할을 하기 때문에(Richardson, Dick, and Jain 1994) 갭 3에 포함될 수도 있다. 실제로 $\mathrm{PZB}(1985,1988 \mathrm{a}, \mathrm{b}, 1994)$ 의 갭 모델에 서는 가격과 커류니케이션울 같은 갭으로 분류하고 있다.

끝으로 설흑 잽 스키마타가 우수하더라도 McCarthy(1960) 이후 근 40여년 동안 뿌리 내린 $4 \mathrm{P}$ 스키마타란 연구자나 실무자의 스키마를 어떻게 조정하도록 설득할 것인지가 과제로 남 는다. 신제품을 판매하는 마케터는 광고나 딴촉올 통해 기존제품에 대한 스키마률 바꾸려 하지만 지식의 생산자가 이를 확산시키는 것은 전혀 다른 문제이기 때문이다. 


\section{참 고 문 헌}

최우원(1999), "신규진입상표의 포지셔넝전략이 소비자의 기역, 푠단 및 선택에 미치는 영 영향," 박사학위논문, 훙익대학교 대학원.

Aaker, David A.(1998), Strategic Market Management, 5th., New York: John Wiley and Sons, Inc. Ailloni-Charas, Dan(1984), Promotion: a Guide to Effective Promotional Planning, Strategies, and Exectutions, New York: John Wiley and Sons, Inc.

Bennett, Peter D.(1988), Marketing, New York: McGraw-Hill.

Bonoma, Thomas V.(1984), "Making Your Marketing Strategy Work," Harvard Business Review, 62(January-February), 23 -39.

Booms, Bernard H. and Mary Jo Bitner(1981), "Marketing Strategies and Organizational Structure for Service Firms," in Marketing of Services, eds. J. H. Donnelly and W. R. George, Chicago: American Marketing Association, 47-51.

Borden, Neil H.(1964), "The Concept of the Marketing Mix," Journal of Advertising Research, 4(June), 2-7.

Cespedes, Frank V.(1995), Concurrent Marketing, Boston, MA: Harvard Business School Press.

Cespedes, Frank V.(1986), Organizing and Implementing the Marketing Effort, Reading, MA: Addison Wesley.

Cravens, David W. and Robert B. Woodruff(1986), Marketing, Reading, MA: Addison-Wesley. Felton, Arthur P.(1959), "Making the Marketing Concept Work," Harvard Business Review, 37(July August), 55-65.

Frey, Albert W.(1956), The Effective Marketing Mix: Programming for Optimum Results, Hanover, NH:

The Amos Tuck School of Business Administration, Dartmouth College.

Gronroos, Christian(1984), "A Service Quality Model and Its Marketing Implications," European Journal of Marketing, 18(4), 36-44.

Hunt, Shelby D.(1991), Modern Marketing Theory: Critical lssues in the Philosophy of Marketing Science, Reading, MA: South-Western Pubishing Company.

Hunt, Shelby D.(1983), "General Theories and the Fundamental Explananda of Marketing," Journal of Marketing, 47(Fall), 9-17.

Kardes, Frank R.(1999), Consumer Behavior and Managerial Decision Making, Addison- Wesley.

Kohli, Ajay K. and Bernard J. Jaworski(1990), "Market Orientation: The Construct, Research

Propositions, and Managerial Implications," Journal of Marketing, 54(April), 1-18.

Kotler, Philip(1997), Marketing Management, 9th ed., New York: Prentice Hall.

Lele, Milind M. and Jagdish N. Sheth(1987), The Customer Is Key, John Wiley.

Lyonski, Steven(1985), “A Boundary Theory Investigation of the Product Manager's Role," Journal of Marketing, 49(Winter), 26-40.

Maddox, R. Neil(1981), "Two-Factor Theory and Consumer Satisfaction: Replication and Extension," Journal of Consumer Research, 8(June), 97-102. 
McCarthy, E. Jerome(1960), Basic Marketing: A Managerial Approach, Irwin.

McNamara, Carlton P.(1972), "The Present Status of the Marketing Concept," Journal of Marketing, 36(January), 50-57.

Naumann, Earl(1995), Creating Customer Value: The Path to Sustainable Competitive Advantage,

Cincinnati, Ohio: Thomson Executive Press.

Oliver, Richard L.(1997), Satisfaction: A Behavioral Perspective on The Consumer, New York: McGrawHill.

Oxenfeldt, Alfred R.(1962), "The Formulation of a Market Strategy," in Managerial Marketing: Perspectives and Viewpoints, Eugene J. Kelly and William Lazer, eds., Homewood, IL: Irwin, 34-44.

Parasuraman, A., Valarie A. Zeithaml, and Leonard L. Berry(1994), "Reassement of Expectations as a Comparison Standard in Measuring Service Quality: Implications for Future Research," Journal of Marketing, 58(January), 111-124.

Parasuraman, A., Valarie A. Zeithaml, and Leonard L. Berry(1988 a), "Communication and Control Processes in the Delivery of Service Quality," Journal of Marketing, 52(April), 35-48.

Parasuraman, A., Valarie A. Zeithaml, and Leonard L. Berry(1988 b), "SERVQUAL: A Multiple Item Scale for Measuring Consumer Perception of Service Quality," Journal of Retailing, 64(Spring), 12 40.

Parasuraman, A., Valarie A. Zeithaml, and Leonard L. Berry(1985), "A Conceptual Model of Service Quality and Its Implications for Future Research," Journal of Marketing, 49(Fall), 41-50.

Reidenbach, R. Eric and Terence A. Olivia(1981), "General Living Systems Theory and Marketing: A Framework for Analysis," Journal of Marketing, 45(Fall), 30-7.

Rchardson, Paul S., Alan S. Dick, and Arun K. Jain(1994), "Extrinsic and Intrinsic Cue Effects on Perceptions of Store Brand Quality," Journal of Marketing, 58(October), 28-36.

Rust, Roland T., Anthony J. Zahorik, and Timothy L. Keiningham(1995), "Retum on Quality(EOQ):

Making Service Quality Financially Accountable," Journal of Marketing, 59(April), 58-70.

Schneider, Benjamin and Daniel Schechter(1991), "Development of a Personnel Selection System for Service Jobs," in Service Quality: Multidisciplinary and Multinational Perspectives, eds. Stephen W.

Brown, Evert Gummesson, Bo Edvarsson, and BengtOve Gustavsson, Lexington Books, 217-236.

Shapiro, Benson P.(1985), "Rejuvenating the Marketing Mix," Harvard Business Review, 63(SeptemberOctober), 28-34.

Sheth, Jagdish N., David M. Gardner, and Dennis E. Garett(1988), Marketing Theory: Evolution and Evaluation, New York: John Wiley \& Sons, Inc.

Schultz, Don E.(1987), "Above or Below the Line? Growth of Sales Promotion in the United States," International Journal of Advertising, 6(1), 17-27.

Strang, Roger A.(1976), "Sales Promotion: Fast Growth, Faulty Management," Harvard Business Review,

54(July-August), 115-24. 
Swan, John E. and Linda Jones Combs(1976), "Product Performance and Consumer Satisfaction: A New Concept," Journal of Marketing, 40(April), 25-33.

Waterschoot, Walter van and Christophe Van den Bulte(1992), "The 4P Classification of the Marketing Mix Revisited," Journal of Marketing, 56(October), 83-93.

Wind, Yoram and Thomas S. Robertson(1983), "Marketing Strategy: New Directions for Theory and Research," Journal of Marketing, 47(Spring), 12-25.

Zeithaml, Valarie A.(1988), "Consumer Perceptions of Price, Quality, and Value: A Means-End Model and Synthesis of Evidence," Journal of Marketing, 52(July), 2-22. 